\title{
Hypocalcaemic cataract as a presenting symptom of renal insufficiency
}

\author{
G. Q. KAZI* \\ M.B., F.R.C.S.(G.)
}

A. T. LAMBIE $\ddagger$

M.B., F.R.C.P.(Edin, Lond)

\author{
C. I. PHILliPS $\dagger$
}

Ph.D., M.D., D.P.H., F.R.C.S. (Edin, Lond

*Department of Ophthalmology, †Princess Alexandra Eye Pavilion, $\ddagger$ Department of Medicine, University Edinburgh and §Medical Renal Unit, Royal Infirmary, Edinburgh

\section{Summary}

A young man of 17 years presented with bilateral reduced vision because of cataracts. Investigations showed a low level of serum calcium along with other evidence of renal failure. The cataracts were mainly in the posterior pole (cupulliform); faint peripheral cortical opacities were also present-in the form of about a dozen half-loops straddling the equator and extending about half way towards the axial centre of the lens.

KEY WORDS: renal hypoplasia.

\section{Introduction}

This patient is reported because visual loss due to hypocalcaemic cataracts was the presenting symptom of renal failure. Although hypocalcaemia is common in renal failure, only three cataracts secondary to hypocalcaemia have been described to our knowledge (Berlyne, Danovitch and Ben-Ari, 1972; Stein and Godel, 1980). This may be partly because the hypocalcaemia is expected and treated, and partly because a duration of hypocalcaemia of around 6-12 months seems to be required to produce these cataracts (Berlyne et al., 1972). It is rather surprising that cataracts are not more common in renal failure since uraemia, hypertension and other cataractinducing conditions co-exist (Clayton et al., 1980), albeit for a relatively short time. These potential adjuvants may explain the different morphology of this patient's cataracts from others.

\section{Case report}

A young white male aged 17 years attended with a complaint of poor vision in both eyes for about 9

Address for reprints: Professor C. I. Phillips, Eye Pavilion, Chalmers Street, Edinburgh EH3 9HA. months. He had had no serious illnesses, exposure. drugs, injury or radiation and there was no famiły history of poor vision. His parents were not consagh guineous.

Examination suggested abnormal skin pallor b $\overrightarrow{u t}$ his mother said this was normal for him and that ligs general health was always excellent. Visual acuify was 6/18 (right) and 6/24 (left) because of bilatem posterior cortical, cupulliform-pattern catargets There were also about a dozen half-loops of peripheral cortical opacities straddling the equititor and extending half way towards the centre offrge lenses. These characteristics are morphologicaly unlike those of congenital cataracts, although, in a gy case, symptoms of visual impairment had started only 9 months previously, and the opacification wes subsequently progressive.

At first, diabetes mellitus was suspected but urige was free from sugar on several occasions. Following the suspicion of hypocalcaemia, the following abne mal results were obtained: plasma calcium 1.25 $\mathrm{mmol} /$ litre (normal 2.12-2.62); phosphate $3.5 \mathrm{mmow}$. litre (normal 0.8-1.4); creatinine 1,000 $\mu \mathrm{mol} /$ litioe (normal 55-150); blood urea $44.5 \mathrm{mmol} /$ litre (norm? 2.5-6.6); creatinine clearance $6 \mathrm{ml} / \mathrm{min}$ (normal 100 $\mathrm{ml} / \mathrm{min}$ ); alkaline phosphatase $13 \mathrm{KA}$ units (normal $10 \mathrm{KA}$ units); haemoglobin $6 \mathrm{~g} / 100 \mathrm{ml}$ (normal 13. $18 \mathrm{~g} / 100 \mathrm{ml}$ ).

A diagnosis of chronic renal failure, possibly de to hypoplastic kidneys, was made. There was evidence of soft tissue calcification on X-ray in spige of the severe hyperphosphataemia.

Nine months after presentation, he required hake modialysis and 4 months later he had a cadaver rengh transplant, which was lost following rejection after months.

About 6 months after presentation, his visu@i acuity had deteriorated considerably $(6 / 36$ in the right eye and $6 / 24$ in the left) so that a riggt 
extracapsular cataract extraction was done with $6 / 4$ result. Operation on the left eye was postponed until 4 years later when a similar operation achieved a $6 / 6$ result in the left eye. $\mathrm{He}$ is currently well on haemodialysis.

\section{Discussion}

It is very rare for an older child or young adult to present with recently developed progressive cataracts; diabetes mellitus would be the usual explanation. Hypocalcaemia due to renal failure is probably less rare than the paucity of previous reports in the literature suggest (Berlyne et al., 1972; Stein and Godel, 1980).

Although iridescent particles occur in hypocalcaemic cataracts (Duke-Elder, 1965; Stein and Godel, 1980), they were not observed in our patient. 'Punctate stippling' in the lenses was observed in about half of a series of 23 patients with renal failure of whom five had serum calcium of less than $6 \mathrm{mg}$ per $100 \mathrm{ml}$ (Berlyne et al., 1972), and in a patient with hypocalcaemic cataract (Stein and Godel, 1980). The involvement of the posterior pole was prominent in our patient and in the other most recently described patient (Stein and Godel, 1980). The latter may also have had cortical opacities similar to the ones we describe as straddling the equator.

The possible contribution of relative hypocalcaemia to the aetiology of 'senile' cataract (Clayton $e t$ al., 1980) will remain an open question until further evidence is accumulated.

\section{References}

Berlyne, G.M., DANovitch, G.M. \& BeN-ARI, T (1972) Cataracts of chronic renal failure. Lancet, i, 509.

Clayton, R.M., Cuthbert, J., Phillips, C.I., Bartholomew, R.S., Stokoe, N.L., FFytChe, T., Reid, J.McK., DufFY, J., SeTH, J. \& ALEXANDER, M. (1980) Analysis of individual cataract patients and their lenses: a progress report. Experimental Eye Research, 32, 553.

DUKE-ELDER, S. (1965) System of Ophthalmology, XI, p. 175. Henry Kimpton, London.

STEIN, R. \& GoDEL, V. (1980) Hypocalcaemic cataract. Journal of Paediatric Ophthalmology and Strabismus, 17, 159.

(Accepted 9 March 1983) 